\title{
A NEW SCLERORHYNCHIFORM (ELASMOBRANCHII) FROM THE MIDDLE CRETACEOUS OF BRAZIL
}

\author{
AGOSTINHAARAUJO PEREIRA \\ Centro de Pesquisa de História Natural e Arqueologia do Maranhão, Rua do Giz, 59, Centro, 65010-680, \\ São Luís, MA, Brasil.agostinhap@yahoo.com.br \\ MANUELALFREDO MEDEIROS \\ Depto. de Biologia, UFMA, Campus do Bacanga, 65080-040, São Luís, MA, Brasil.alf@ufma.br
}

\begin{abstract}
A new species and a new genus of sclerorhynchids (Elasmobranchii), Atlanticopristis equatorialis, is recorded from the early Cenomanian deposits of the Alcântara Formation, Itapecuru Group of northeastern Brazil. Fourteen rostral teeth were collected at the Falésia do Sismito exposure, Cajual Island, northern Maranhão State. The holotype, VT1174 , is slightly recurved and compressed, $15 \mathrm{~mm}$ long, including the penducle, which is $6.3 \mathrm{~mm}$ long antero-posteriorly, and has a thickness of $3 \mathrm{~mm}$. Both sides are barbed in all specimens. VT-1174 exhibits 4 barbs along the anterior margin and 5 on the posterior one. Barb number varies among the specimens; some specimens possess more barbs than the holotype, and one specimen has more barbs on the anterior margin than on the posterior one. On dorsal and ventral faces, nearly straight enameloid ridges emanate from the crown base. They diverge from each other apically, forming the frame of a fan. More lateral ribs intersect the base of a barb, but central ribs are nearly parallel and terminate close to the base of the crown. On some specimens, more lateral enameloid ridges fail to reach more apical barbs. Some specimens exhibit a medial longitudinal groove on both surfaces. The peduncle is antero-posteriorly expanded and irregularly fluted, laterally compressed, tending to be ellipsoidal or sub-rectangular in basal outline. This new taxon occurs in the same estuarine deposits where Onchopristis numidus was previously reported, thus increasing the known diversity of fishes, Elasmobranchii in particular, from the middle Cretaceous of northeastern Brazil.
\end{abstract}

Key words: Atlanticopristis equatorialis, Elasmobranchii, Rajiformes, Sclerorhynchidae, Cretaceous.

RESUMO - Uma nova espécie e um novo gênero de sclerorhynchideos (Elasmobranchii), Atlanticopristis equatorialis, é registrada nos depósitos eocenomanianos da Formação Alcântara, Grupo Itapecuru, nordeste do Brasil. Quatorze dentes rostrais foram coletados no afloramento Falésia do Sismito, na Ilha do Cajual, norte do estado do Maranhão. O holótipo, VT-1174, é levemente recurvado e comprimido, com $15 \mathrm{~mm}$ de comprimento, incluindo o pedúnculo que tem dimensão antero-posterior de 6,3 mm, com uma espessura máxima de $3 \mathrm{~mm}$. Em todos os espécimes ambas as bordas são farpadas. VT-1174 apresenta 4 farpas ao longo da margem anterior e 5 na posterior. O número de farpas varia entre os espécimes; alguns apresentam mais farpas que o holótipo, e um deles apresenta mais na margem anterior que na posterior. Nas faces dorsal e ventral estrias do esmalte quase retilíneas surgem na base da coroa. Distalmente, elas divergem umas das outras, formando a figura de um leque, cada uma delas alcançando a base de uma farpa, exceto as mais centrais que se mantêm quase paralelas e desaparecem distalmente, logo após a base da coroa. Em alguns espécimes as estrias laterais do esmalte não alcançam as farpas mais distais; outros apresentam uma depressão longitudinal mediana em ambas as superfícies. O pedúnculo é expandido e irregularmente sulcado, lateralmente comprimido, tendendo a um contorno basal elipsoidal ou subretangular. Esta nova forma ocorre nos mesmos depósitos estuarinos onde Onchopristis numidus foi previamente registrada, aumentando a diversidade de peixes, Elasmobranchii em particular, no meso-Cretáceo do nordeste do Brasil.

Palavras-chave: Atlanticopristis equatorialis, Elasmobranchii, Rajiformes, Sclerorhynchidae, Cretáceo.

\section{INTRODUCTION}

Cretaceous sawfishes assembled in the family Sclerorhynchidae are known from the lower Cretaceous to Maastrichtian. Because these fish were cartilaginous, although some skeletons exceptionally well preserved have been found, most of their record is represented by rostral teeth that are more easily fossilized (Stromer, 1917; Arambourg, 1940; Schaeffer, 1963; Cappetta, 1987; Kirkland \& AguillónMartinez, 2002, Kriwet, 2004).
The development of a long rostrum armed with spines along sides may be related to their feeding habits-mudgrubbing and/or slashing their prey (Breder, 1952; Schaeffer, 1963; Kirkland \& Aguillón-Martinez, 2002). Curiously, Mesozoic sawfishes exhibited rostral dentition similar to extant sawsharks (Pristiophoridae). However, this is considered as a case of convergent evolution and the Cretaceous batoid group is more closely related to living sawfishes (Pristidae). As in living pristiophorids, the rostral teeth of Cretaceous sawfishes were attached to the lateral 
edges of the rostrum via ligaments. This mode of attachment is considered a primitive condition and is distinct from extant Pristids which have teeth inserted into alveoli. Historically, the similarity has caused some confusion in the identification of some isolated rostral teeth (Arambourg, 1940; Slaughter \& Springer, 1968).

Morphological terminology for Cretaceous sawfish rostral teeth was provided by Arambourg (1940). The rostral teeth are composed of two distinct parts, a crown and peduncle (base). The crown morphology varies considerably among the various genera, but is generally dorsoventrally compressed and covered by enameloid, and anterior and posterior margins are sharp at least on the more basal and apical portions. The peduncle varies in length, is devoid of enameloid and is expanded basally. Varying degrees of ribbing or fluting are developed, which would be useful for attachment of ligaments involved in the fixation of the tooth to the lateral edge of the rostrum. The basal surface of the peduncle is usually concave, and exhibits a straight exit of the pulp canal. Because the only material generally preserved is isolated rostral teeth, the taxonomy of Cretaceous sawfishes is primarily based on their morphological variation. Based on cladistic analysis, Kriwet (2004) assumed a monophyletic arrangement to the Sclerorhynchidae.

\section{The Itapecuru Group}

The faunule of fossil fishes preserved in the Itapecuru Group, which includes the Albian unnamed unit, the Alcântara Formation (Late Albian to Early Cenomanian), and the Cujupe Formation (Upper Cretaceous to ?Tertiary) (Figure 1), has only recently been sufficiently documented to be confidently placed into a paleobiogeographic context. The Cretaceous sedimentary sequences extend along central and northern Maranhão State, northeastern Brazil, and document the history of rifting between South America and Africa (Mesner \& Wooldridge, 1964; Aranha et al. 1990; Pedrão at al., 1993 a, b, c; and see revision in Rossetti et al., 2001). The Alcântara Formation, outcropping on the coastal cliffs of São Marcos Bay (Figure 2), along the northern coastline (Rossetti \& Truckenbrodt, 1997; Rossetti, 1998), has yielded an expressive fossil record of continental and marine vertebrates (Medeiros \& Schultz, 2001, 2002; Medeiros et al., 2007; Vilas Bôas \& Carvalho, 2001).

Fish fossils, although in a fragmentary condition, are well documented in the Albian and Cenomanian deposits of the Itapecuru Group, and assemblages contain a mixture of marine, freshwater and estuarine forms. Taxa previously reported include the species Ceratodus africanus, Protopterus humei, Asiatoceratodus tiguidiensis, Mawsonia gigas, Onchopristis numidus, and unidentified species of Lepidotes, Tribodus, Bartschichthys, Eotrigonodon, Stephanodus and Myliobatis, along with undetermined forms of pycnodontids, lepisosteids, and Amiids (see Cunha \& Ferreira, 1980; Dutra \& Malabarba, 2001; Eugênio, 1994; Medeiros \& Schultz, 2001, 2002; Pereira \& Medeiros, 2003; Marques da Silva \& Medeiros 2003; Castro et al., 2004; Sousa

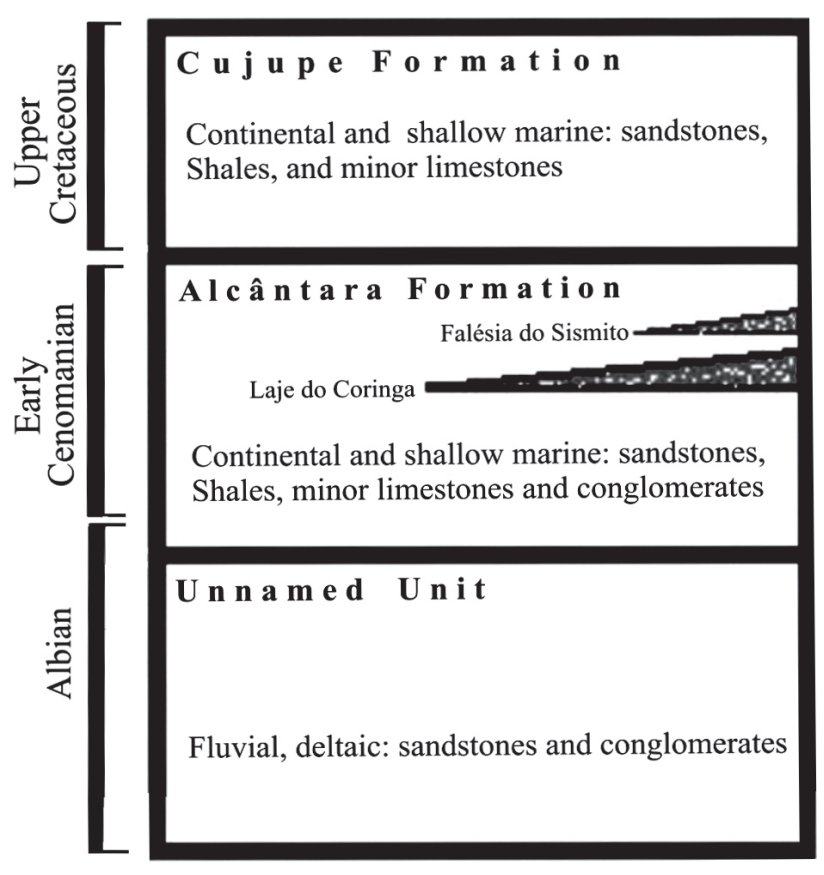

Figure 1. Stratigraphic scheme showing the lithologies and subdivisions of the Itapecuru Group, and indicating the Early Cenomanian main fossiliferous conglomeratic levels of the Alcântara Formation: Laje do Coringa and Falésia do Sismito.

et al., 2004; Toledo et al., 2005). Marine invertebrates have also been reported in an Early Cenomanian stratum of the Alcântara Formation, including the mollusks Brachidontes, Inoceramus, Chlamys, Neithea, Plicatula, Acesta, Lopha, Pterotrigonia and Mulinoides (Klein \& Ferreira, 1979). A nearshore marine ichnofossil assemblage, including Skolithos, Ophiomorpha, Planolites, Arenicolites, Cylindrychnus, and Thallassinoides have also been reported for this sedimentary unit (Rossetti, 1997). In this report, we describe rostral spines that represent a new genus and species of sclerorhynchid ray that occurs in the Alcântara Formation.

\section{MATERIAL AND METHODS}

The rostral teeth were collected by sieving conglomeratic sediments from the Falésia do Sismito site as it was being exposed by the action of the waves. This site is located on the eastern side of Cajual Island $\left(2^{\circ} 28^{\prime} 43.0^{\prime \prime} \mathrm{S}\right.$; $44^{\circ} 28^{\prime} 10.3^{\prime \prime}$ W), Alcântara Formation (Early Cenomanian), Itapecuru Group, in northern Maranhão State, located in northeastern Brazil (Figure 2). The fossiliferous site is a poorly cemented conglomerate level, just a few centimeters high (Pereira \& Medeiros, 2003), which is part of an estuarine complex formed by stratified sandstones, showing parallel, tangential and swaley cross bedding, interpreted as tidal sand bars of a flood tidal delta complex, and a rhythmic sandstone/mudstone facies of a subtidal bayfill (Holz, 2003).

The14 specimens assigned to the new species are housed in the paleontological collection of the Centro de Pesquisa de História Natural e Arqueologia do Maranhão (CPHNAMA) in the city of São Luís. The materials were identified after 


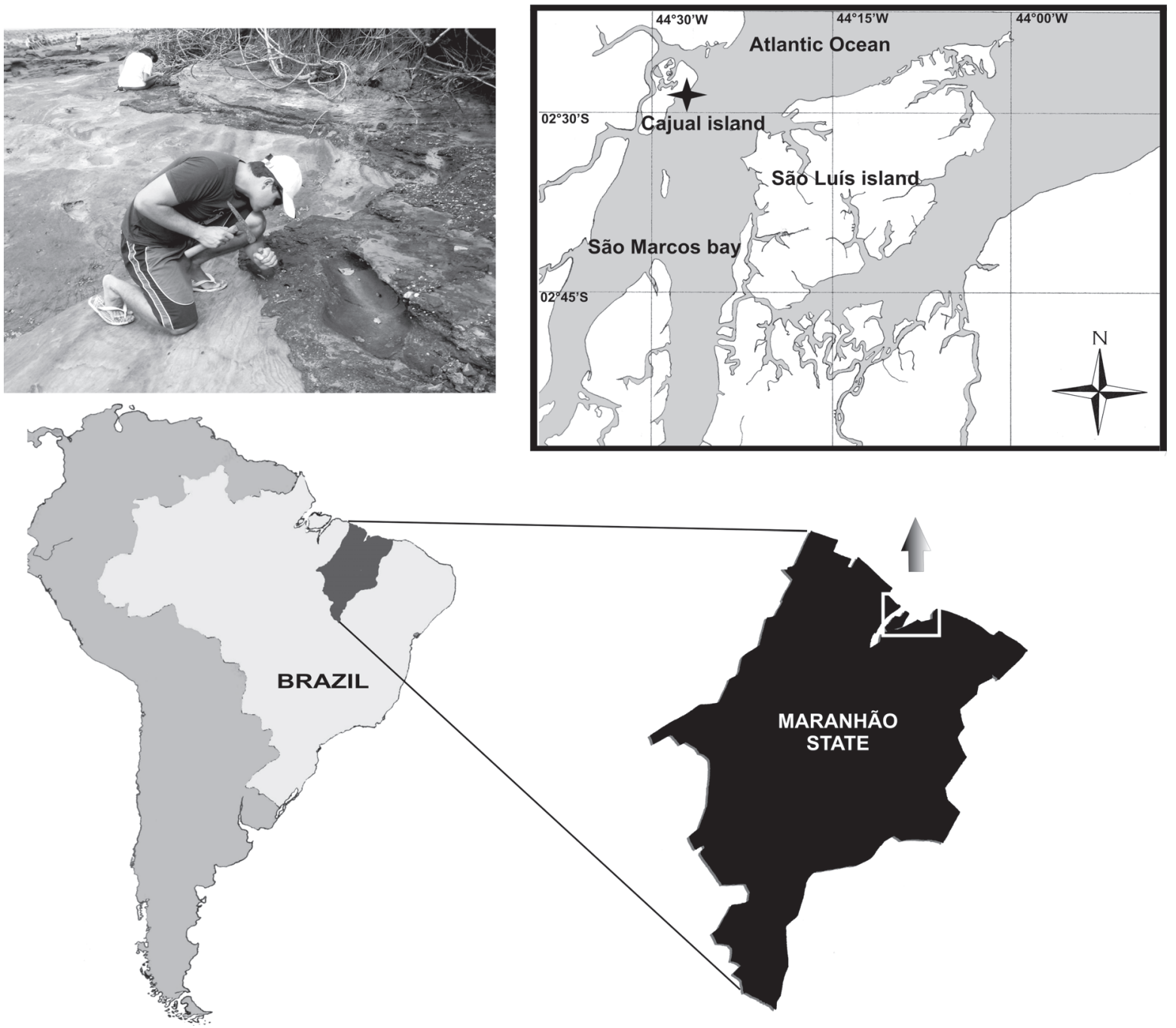

Figure 2. Location map of the Falésia do Sismito site (black star) in the Cajual Island, northern Maranhão State, northeastern Brazil. The conglomeratic fossiliferous level is shown on the photo.

analysis using a binocular microscope. The specimens were measured and compared to each other, and the holotype was chosen based on quality of preservation and possession of the most diagnostic characteristics for the taxon.

\section{SYSTEMATIC PALEONTOLOGY}

Class CHONDRICHTHYES Huxley, 1880 Subclass ELASMOBRANCHII Bonaparte, 1838

Superorder PRISTIORAJEA Carvalho, 1996 Order SCLERORHYNCHIFORMES Kriwet, 2004 Family SCLERORHYNCHIDAE Cappetta, 1974

\section{Atlanticopristis n. gen.}

Diagnosis. Rostral teeth with multibarbed anterior and posterior margins, extensive enameloid ribbing on dorsal and ventral surfaces; centralized ribs are parallel and confined to the more proximal portion of the crown, with peripheral ribs forming progressively wider angles in relation to the longitudinal axis of the tooth, resulting in a fan-like appearance. Etymology. Atlantico in reference to the Atlantic Ocean in which sediments of the Alcântara Formation were deposited; and pristis, from the Greek, meaning sawfish.

\section{Atlanticopristis equatorialis n. $\mathrm{sp}$.}

(Figure 3)

Holotype. CPHNAMA-VT 1174, a complete rostral tooth. Paratypes. 14 specimens including CPHNAMA-VT 1085 (2), CPHNAMA-VT 1086, CPHNAMA-VT 1088 (4), CPHNAMAVT 1172 (4), CPHNAMA-VT 1173 (2).

Locality and horizon. Falésia do Sismito, Cajual Island $\left(2^{\circ}\right.$ $28^{\text {‘ }} 43,0^{\prime \prime} \mathrm{S} ; 44^{\circ} 28^{\prime}$ 10,3“ W), Alcântara Formation (Early Cenomanian), Itapecuru Group, northern Maranhão State, northeastern Brazil (Figure 2).

Etymology. equatorialis due to the proximity of the collecting site to the equator.

Diagnosis. Same as for genus.

Description. CPHNAMA-VT 1174 is a complete specimen 

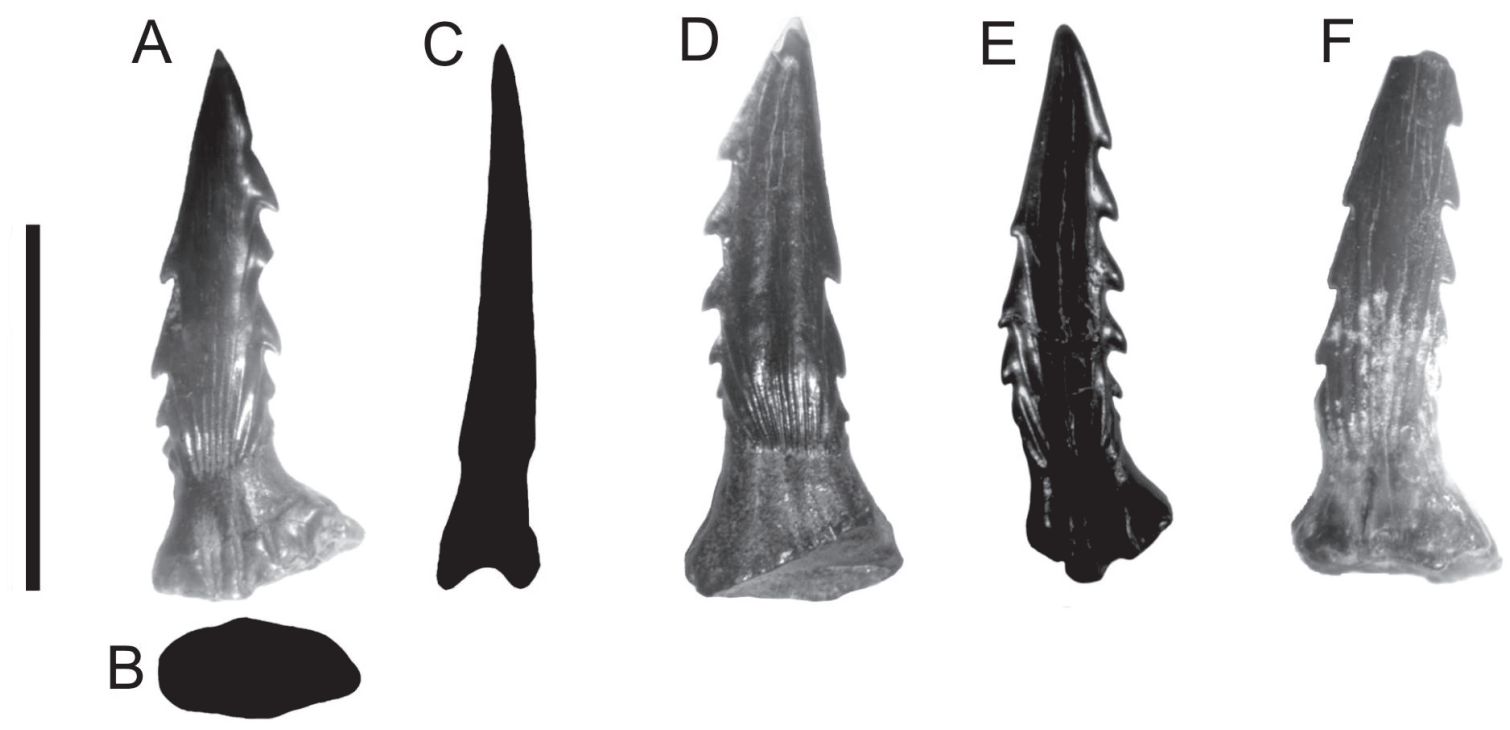

Figure 3. Atlanticopristis equatorialis rostral teeth. A-C, VT-1174, holotype; B, outlines of the peduncle base; C, outline of the complete tooth in posterior view; D, VT-1086, a paratype, which, differently from the other specimens, is recurved anteriorly; E-F, VT-1085, paraypes. Scale bar $=1 \mathrm{~cm}$.

that is dorsoventrally compressed and slightly recurved posteriorly (Figure 3A, C), $15 \mathrm{~mm}$ long (including the penducle), with 4 barbs on the anterior margin and 5 on the posterior one. Nearly straight enamel ribs emanate from the base of the crown and spread onto dorsal and ventral faces, diverging apically to form the outline of a fan, each of them meeting the base of a barb, except the more central ones that are maintained almost in parallel and are confined to the more basal portion of the cap. The irregularly grooved peduncle is dorsoventrally compressed (Figure 3A, B) and expanded beyond the anterior and posterior edges of the crown. The basal outline is ellipsoidal and the attachment surface is concave (Figure 3B, C). The peduncle measures $6.3 \mathrm{~mm}$ anteroposteriorly and $3 \mathrm{~mm}$ dorsoventrally.

CPHNAMA-VT 1086 is a complete specimen slightly curved anteriorly (Figure 3D), $18.8 \mathrm{~mm}$ long. The cap is $4 \mathrm{~mm}$ wide anteroposteriorly, with a maximum thickness of $2 \mathrm{~mm}$ in the basal portion. The specimen exhibits 3 barbs on the anterior margin, but a vestigial basal protuberance could be considered a $4^{\text {th }}$ barb; 5 barbs are found along the posterior margin (the basal one being very small). CPHNAMA-VT 1085 contains one complete specimen, $18.7 \mathrm{~mm}$ long (Figure $3 \mathrm{E}$ ), and one just a few millimeters smaller, but lacking a fragment of the tip (Figure 3F). Both specimens possess 3 clearly distinguishable barbs on the anterior margin, and a basal protuberance that could be considered a $4^{\text {th }}$ barb. There are 5 distinguishable barbs on the posterior margin. Again, a vestigial protuberance on the more basal portion of the complete specimen may be considered a tiny $6^{\text {th }}$ barb. Lot CPHNAMA-VT 1088 includes 4 incomplete specimens, all them lacking the crown tip, 3 of them with complete peduncle, and one retaining only the distal portion of this structure. The largest specimen is $18 \mathrm{~mm}$ in length and the shortest one $13.8 \mathrm{~mm}$. There is a maximum of 4 barbs on the anterior margins and 5 distinguishable posterior barbs. CPHNAMA-VT 1172 consists of 4 incomplete specimens, all of them including the peduncle and part of the crown (but lacking the tip). The smallest specimen measures $11.5 \mathrm{~mm}$ apical-basally, and the largest $13.5 \mathrm{~mm}$. The range of variation in the number of barbs is not greater than in the specimens described above. Lot CPHNAMA-VT 1173 has 2 incomplete specimens preserving almost all the crown. One of them (14.5 $\mathrm{mm}$ in length) bears two anterior barbs and 5 posterior ones, while the other (11.5 $\mathrm{mm}$ in length) bears 3 anterior barbs and 4 posterior ones.

\section{DISCUSSION}

Pereira \& Medeiros (2007) originally identified the spines discussed here as Onchopristis sp. based on the similarity of the peduncle, formation of multiple barbs, and presence and pattern of enamel ribbing on the crown faces. However, after a critical reevaluation, we believe that the new material exhibits a unique combination of characteristics that differentiate the rostral teeth from those of Onchopristis and all other sclerorhynchids, and thus, a new genus is proposed. Nonetheless, we are aware that it is so closely related to Onchopristis that any other subjective interpretation could consider them as synonym. Rostral spines with both sides multibarbed are also seen in the sawshark Ikamauius, from New Zealand (Keyes, 1979), but differences in symmetry and relative length of the crown, number and shape of barbs, and morphology of the peduncle do not indicate close taxonomic relationships between our material and the pristiophorid Ikamauius. Furthermore, sawsharks usually occur in deep marine environments, whereas sawfishes are commonly found in shallow water sediments or even associated with estuarine deposits (Schaeffer, 1963). The Alcântara Formation was formed under estuarine to shallow marine conditions (Mesner 
\& Wooldridge, 1964; Cunha \& Ferreira, 1980; Rossetti \& Truckenbrodt, 1997), and rostral teeth are associated with material of continental origin, including dinosaur bones and teeth, crocodiles, freshwater and saltwater fishes, and fossilized trunks of conifers and ferns (Medeiros \& Schultz, 2001, 2002; Medeiros et al., 2007). The geological setting of the region in which our rostral teeth are found is similar to that of Pucapristis branisi from the El Molino Formation, Bolivia (Schaeffer, 1963). Actually, there are similarities between the rostral teeth from the Alcântara Formation (Onchopristis and Atlanticopristis) and Pucapristis branisi; this Bolivian form possesses one posterior barb and longitudinal enamel ribbing, but the peduncle is otherwise very different. Cappetta (1987) distinguished two different groups in the Sclerorhynchidae, separating Pucapristis from Onchopristis.

Concerning the barb number, Atlanticopristis equatorialis is more similar to Onchopristis dunklei McNulty \& Slaughter 1962. More than one barb on the posterior margin is a character rare in $O$. numidus and constant in $O$. dunklei; the enamel ribbing are present in $O$. numidus and at least in some rostral teeth of O. dunklei (McNulty \& Slaughter, 1962; Slaughter \& Steiner, 1968; Cappetta, 1987) as are also in Atlanticopristis equatorialis. Another sclerorhynchid genus with barbed spines, Borodinopristis (see Case, 1987), is so obviously distinct from Atlanticopristis in the proportions and general aspects of the morphology, that no close relationship can be suggested.

Onchopristis numidus has been reported from the same Early Cenomanian deposits of the Alcântara Formation (Pereira \& Medeiros, 2007) where Atlanticopristis equatorialis was collected, but it is important to note that no intermediate form was found betwen the morphology of Onchopristis and Atlanticopristis, and they are easily differentiated, indicating that they belong to different taxa.

Most of the fossiliferous record of the Alcântara Formation comes from the outcrops along the Ilha do Cajual coastal cliffs, where the sedimentary sequence is dominated by sandstones intercalated with mudstones and conglomerates, and it is in these latter where most of the fossil remains are concentrated (Corrêa Martins, 1997; Medeiros \& Schultz, 2001, 2002). The rocks are of marine origin, but most of the fossils represent terrestrial species. Holz (2003) considered the Laje do Coringa site, the richest outcrop, as a transgressive lag formed under shallow marine conditions. Thousands of bone fragments, teeth, and mineralized plant trunks and stems indicate a paleocommunity similar to the chronocorrelate in northern Africa, including conifers and giant ferns, dinosaurs such as Carcharodontosaurus, Spinosaurus, undetermined forms of titanosaurs and at least one species of rebbachisaurid sauropoda, fishes such as Ceratodus africanus, Asiatoceratodus tiguidiensis and Mawsonia, as well as crocodilians and pterosaurs (see revision in Medeiros et al., 2007). The Falésia do Sismito site, part of the same stratigraphic sequence (Figure 1), is located only a few hundred meters from Laje do Coringa, and yielded the same fossil assemblage as well as more delicate specimens such as the rostral teeth. This paleocommunity appears to have persisted in northern and northeastern Brazil from the Albian to Early Cenomanian, and is more similar to the northern African fauna than to the austral South American one. However, some differences have been observed in the fish fauna, particularly in lungfish diversity (Medeiros et al., 2007), but also A. equatorialis, a taxon currently unknown from Africa.

\section{CONCLUSIONS}

The multibarbed rostral teeth collected at the Falésia do Sismito site, Alcântara Formation (Early Cenomanian), northeastern Brazil, represent a new genus and species of sclerorhynchid ray. Atlanticopristis, here considered as belonging to the family Sclerorhynchidae, occurs in the same stratigraphic sequence as its closely related genus, Onchopristis. This new taxon probably inhabited shallow marine waters of the southern Atlantic Ocean, periodically entering into estuarine environments.

\section{ACKNOWLEDGMENTS}

We thank the students of the biological sciences courses of UFMA and CEUMA for help with the fieldwork. This work was financially supported by Secretaria de Cultura do Estado do Maranhão, UFMA and PETROBRAS. We also thank H. D. Cicimurri, C. Underwood and H. Cappetta for the criticism and suggestions.

\section{REFERENCES}

Arambourg, C. 1940. Le group des Ganopristinés. Bulletin de la Société Géologique de France, Ser. 5, 10:127-147.

Aranha, L.G. de; Lima, H.P.; Souza, J.M.P. de \& Makino, R.K. 1990. Origem e evolução das bacias de Bragança-Viseu, São Luís e Ilha Nova. In: G.R. Gabaglia \& E.J. Milani (eds.) Origem e Evolução de Bacias Sedimentares, Petrobras, p. 221-233.

Breder Jr., C.M. 1952. On the utility of the saw of the sawfish. Copeia, 2:90-91.

Cappetta, H. 1974. Sclerorhynchidae nov. fam., Pristidae et Pristiophoridae: un exemple de parallélisme chez les sélaciens. C. R. Academie des Seances, Paris, 278, Serie D:225-228.

Cappetta, H. 1987. Handbook of Paleoichthyology (Vol 3B)Chondrichthyes II. München, Gustav Fischer Verlag, 193 p.

Case, G.R. 1987. Borodinopristis schwimmeri, a new ganopristine swfish from the Upper Blufftown Formation (Campanian) of the Upper Cretaceous of Georgia. Bulletin of the New Jersey Academy of Science, 32(1): 25-33.

Castro, D.F.; Toledo, C.E.V.; Sousa, E.P. \& Medeiros, M.A. 2004. Novas ocorrências de Asiatoceratodus (Osteichthyes, Dipnoiformes) na Formação Alcântara, Eocenomaniano da bacia de São Luís, MA, Brasil. Revista Brasileira de Paleontologia, 7(2):245-248.

Corrêa Martins, F.J. 1997. A Laje do Coringa: um bone-bed da Formação Itapecuru (Cretáceo Superior da Bacia de São Luís-MA). Anais da Academia Brasileira de Ciências, 63 (3):436-437.

Cunha, F.L.S. \& Ferreira, C.S. 1980. Um dipnoi na Formação Itapecuru (Cenomaniano), Maranhão, Brasil. In: CONGRESO ARGENTINO DE PALEONTOLOGIA Y BIOESTRATIGRAFIA, 2, 1980. 
Actas, Buenos Aires, p. 1-9.

Dutra, M.F.A. \& Malabarba, M.C. 2001. Peixes do AlbianoCenomaniano do Grupo Itapecuru no Estado do Maranhão, Brasil. In: D.F. Rossetti; A.M. Góes \& W. Truckenbrodt (eds.) O Cretáceo da Bacia de São Luís-Grajaú, Museu Paraense Emílio Goeldi, p. 191-208.

Eugênio, W.S. 1994. Caracterização Geopaleontológica do Cretáceo da baía de São Marcos, Maranhão, Brasil. Programa de PósGraduação em Geociências, Universidade Federal do Rio de Janeiro, Dissertação de Mestrado, 75 p.

Holz, M. 2003. Sequence stratigraphy as a tool for vertebrate taphonomy-an example from a Late Cretaceous dinosaur taphocenosis from São Luís basin, northern Brazil. In: LATINAMERICAN CONGRESS OF SEDIMENTOLOGISTS, 3, 2003. Belém, MPEG, p. 213-214.

Keyes, I.W. 1979. Ikamauius, a new genus of fossil sawshark (Order Selachii: Family Pristiophoridae) from the Cenozoic of New Zealand. New Zealand Journal of Geology and Geophysics, 22(1):125-129.

Kirkland, J.I. \& Aguillón-Martinez, M.C. 2002. Schizorhiza: a unique sawfish paradigm from the Difunta Group, Coahuila, Mexico. Revista Mexicana de Ciências Geológicas, 19(1):16-24.

Klein, V.C. \& Ferreira, C.S. 1979. Paleontologia e estratigrafia de uma fácies estuarina da Formação Itapecuru, Estado do Maranhão. Anais da Academia Brasileira de Ciências, 51:523-533.

Kriwet, J. 2004. The systematic position of the Cretaceous sclerorhynchid sawfishes (Elasmobranchii, Pristiorajea). In: G. Arratia \& A. Tintori (eds.) Mesozoic Fishes 3-Systematics, Paleoenvironments and Biodiversity, Verlag Dr. Friedrich Pfiel, Munich, Germany, p. 57-73.

Marques da Silva, M.A. \& Medeiros, M.A. 2003. Ocorrência de Tribodus no Eocenomaniano do Maranhão. In: CONGRESSO BRASILEIRO DE PALEONTOLOGIA, 18, 2003. Boletim de Resumos, Brasília, UNB, p. 276-277.

McNulty Jr., C.L. \& Slaughter, B. 1962. A new sawfish from the Woodbine Formation (Cretaceous) of Texas. Copeia, 4:775-777.

Medeiros, M.A. \& Schultz, C.L. 2001. Uma paleocomunidade de vertebrados do Cretáceo médio, bacia de São Luís. In: D.F. Rossetti; A.M. Góes \& W. Truckenbrodt (eds.) O Cretáceo na bacia de São Luís-Grajaú, Museu Paraense Emílio Goeldi, p. 209-221.

Medeiros, M.A. \& Schultz, C.L. 2002. A fauna dinossauriana da Laje do Coringa, Cretáceo Médio do Nordeste do Brasil. Arquivos do Museu Nacional, 60(3):155-162.

Medeiros, M.A.; Freire, P.C.; Pereira, A.A.; Santos, R.A.B.; Lindoso, R.M.; Coêlho, A.F.A; Passos, E.B. \& Sousa Junior, E. 2007. Another African dinosaur recorded in the Eocenomanian of Brazil and a revision on the paleofauna of the Laje do Coringa site. In: I.S. Carvalho; R.T. Cassab; C. Schwanke; M.A. Carvalho; A.C.S. Fernades; M.A.C. Rodrigues; M.S. Carvalho; M. Arai \& M.E.Q. Oliveira (eds.) Paleontologia: Cenários da Vida, Editora Interciência, p. 413-423.

Mesner, J.C. \& Wooldridge, P. 1964. Estratigrafia das bacias paleozóica e cretácea do Maranhão. Rio de Janeiro, Petrobras, p. 137-164 (Boletim Técnico 7).

Pedrão, E.; Arai, M; Barrilari, I.M.R. \& Carvalho, I.S. 1993a. Análise palinológica de uma amostra de superfície de Querru (Formação Itapecuru), Município de Itapecuru Mirim-MA. Rio de Janeiro, Petrobras, 11 p. (Relatório Técnico).

Pedrão, E.; Arai, M.; Carvalho, I.S. \& Ferreira, C.S. 1993b. Palinomorfos de sedimentos albianos (Formação Itapecuru) da Bacia do Parnaíba. Rio de Janeiro, Petrobrás, 13 p. (Relatório Técnico).

Pedrão, E.; Arai, M.; Carvalho, I.S. \& Santos, M.H.B. 1993c. Palinomorfos da Formação Itapecuru - análise palinológica de uma amostra de superfície da Ponta do Farol, São Luís MA. Rio de Janeiro, Petrobras, 10 p. (Relatório Técnico).

Pereira, A.A. \& Medeiros, M.A. 2003. Novas ocorrências de peixes no Eocenomaniano do Maranhão. In: CONGRESSO BRASILEIRO DE PALEONTOLOGIA, 18, 2003. Boletim de Resumos, Brasília, UNB, p. 221-222.

Pereira, A.A. \& Medeiros, M.A. 2007. A new Elasmobranchii form from the Alcântara Formation (Itapecuru deposits; Eocenomanian of Brazil) In: CONGRESSO BRASILEIRO DE PALEONTOLOGIA, 20, 2007. Anais, Búzius, UFRJ, p. 18.

Rossetti, D.F. 1997. Internal architecture of mixed tide-and storminfluenced deposits: an example from the Alcântara Formation, northern Brazil. Sedimentary Geology, 114:163-188.

Rossetti, D.F. \& Truckenbrodt, W. 1997. Revisão estratigráfica para os depósitos do Albiano-Terciário Inferior (?) na bacia de São Luís (MA), norte do Brasil. Boletim do Museu Paraense Emílio Goeldi (Série Ciências da Terra), 9:29-41.

Rossetti, D.F.; Góes, A.M \& Truckenbrodt, W. 2001. O Cretáceo na Bacia de São Luis-Grajaú. Belém, Editora do Museu Paraense Emílio Goeldi, 264 p.

Schaeffer, B. 1963. Cretaceous fishes from Bolívia, with comments on Pristid evolution. American Museum Novitates, 2159:1-20.

Slaughter, B. \& Springer, S. 1968. Replacement of rostral teeth in sawfishes and sawsharks. Copeia, 3:499-506.

Slaughter, B. \& Steiner, M. 1968. Notes on rostral teeth of ganopristine sawfishes, with special reference to Texas material. Journal of Paleontology, 42(1):233-239.

Sousa, E.P.; Medeiros, M.A.; Bertini, R.J.; Pereira, A. \& Toledo, C.E.V. 2004. Ocorrência inédita de picnodontiformes para a Laje do Coringa, ilha do Cajual (Formação Alcântara), Eocenomaniano do estado do Maranhão. In: SIMPÓSIO BRASILEIRO DE PALEONTOLOGIA DE VERTEBRADOS, 4, 2004. Boletim de Resumos, Rio Claro, UNESP, p. 67-68.

Stromer, E. 1917. Ergebnisse der Forschungsreisen von Prof. E. Stromers in den Wüsten Äegyptens, II: Wirbeltierreste der Baharije-Stufe (unterstes Cenoman). 4 - Die Säge des Pristiden Onchopristis numidus Haug sp. und über die Sägen der Sägehaje. Abhandlungen der Königliche Bayerischen Akademie der Wissenschaften, München, Band 28, 8:1-28.

Toledo, C.E.V.; Bertini, R.J.; Sousa, E.P. \& Medeiros, M.A. 2005. First occurrence of Protopterus humei (Dipnoiformes) in South America. In: CONGRESSO LATINO-AMERICANO DE PALEONTOLOGIA DE VERTEBRADOS, 2, 2005. Boletim de Resumos, Rio de Janeiro, MNRJ, p. 262-263.

Vilas Bôas, I.C. \& Carvalho, I.S. 2001. Répteis marinhos (Mosasauria e Plesiosauria) do Cretáceo Superior da Bacia de São Luís (Maranhão, Brasil). In: D.F. Rossetti; A.M. Góes \& W. Truckenbrodt (eds.) O Cretáceo na Bacia de São LuísGrajaú, Museu Paraense Emilio Goeldi, p. 223-233.

Received in August, 2008; accepted in November, 2008. 